\title{
Public-Private Partnership Contracts: A Tale of Two Cities with Different Contractual Arrangements
}

\author{
Rui Cunha Marques \\ Centre of Urban and Regional Systems \\ Technical University of Lisbon
}

\author{
Sanford V. Berg \\ Public Utility Research Center \\ University of Florida
}

January 6, 2010

\begin{abstract}
This paper analyses regulation by contract in public-private partnerships (PPPs) for infrastructure services. Although the benefits of competition for the market and subsequent regulatory contracts are recognised, the literature also identifies contract design failures.

When considering these limitations, it is useful to distinguish between contracts associated with purely contractual PPPs (concessions) and contracts for institutionalised PPPs (mixed company). Two cases from the Portuguese water sector are used to illustrate problems arising in the preparation of public tender documents: the "best" bidder is often not the winner. Often, risks are not allocated correctly nor is effective monitoring ensured. Comparisons between the two types of contracts show how external regulation can be useful in mitigating contractual problems. This examination of bidding procedures and contract design yields several implications for policy-makers; in addition, the study presents recommendations for improving regulatory contracts.
\end{abstract}

Keywords: public-private partnerships; water utilities; concessions; mixed companies; contract design

This paper is a shortened and revised version of "Public-Private Partnership Contracts: A Tale of Two Cities (June 2009-PURC Working Paper) 


\section{INTRODUCTION}

Competition in the market is absent in many infrastructure services. Some segments of network industries, particularly water utilities, are natural monopolies. To achieve production efficiency, such markets should have a single operator. This situation can harm the public interest when there are excess profits (redistributing income from customers to the monopolist) and reduced output causing misallocations (deadweight losses). Without pressure from the capital market, the monopolist prefers the "quiet life": incentives for production efficiency are blunted. One public policy response is to create a sector regulator with the responsibility for promoting better performance and meeting social concerns: ideally, to achieve levels of allocative efficiency comparable to those arising in the competitive marketplace and to achieve public policy objectives. Of course, the sector regulator faces significant problems related to expertise and autonomy, information asymmetries, regulatory capture, opportunism and authority.

An alternative to competition in the market is competition for the market (Chadwick, 1859). In this case, the right to operate a monopoly is subject to an auction. The winning bid would be the one to present the best offer (lower cost or higher rent), guaranteeing that in a situation of sufficient competition (no collusive behaviour) the winner would offer an average price close to the average cost, allowing for fair and reasonable profits (Demsetz 1968). The conditions of operation (rights and duties) are signed in a written contract, leading to the term 'regulation by contract'. The modern version of this kind of relationships is labelled public-private partnership (hereafter, PPP). Indeed, a PPP is a form of public procurement with cooperation between a public authority and a private partner aimed at ensuring the funding, construction, renewal, management and/or maintenance of infrastructure, or the provision of a related service.

In the EU, PPPs are classified into institutionalised PPP (mixed companies) and purely contractual PPPs [see about PPPs for infrastructures and provision of services in the EU and their classification the $\operatorname{COM}(2004) 327, \operatorname{COM}(2005) 569$ or $\mathrm{C}(2007) 6661]$. These two models have very different features which are studied here with reference to two municipalities. Purely contractual PPPs comprise concession, affermage, and management contracts. Note that outright divesture is not considered a PPP. Some features of PPP contracts include the sharing of responsibilities and risks between the public and private partners (in principle, risk is allocated to the partner better able to manage and mitigate it), a project life-cycle approach, and incentive (output) payment schemes.

The impact of private sector participation and PPP contracts in infrastructure, including water, has been often positive (Gassner et al. 2009). Most PPP contracts have provided value for money and have helped to solve serious problems of coverage and quality of service both in the developed and developing world. However, some outcomes have been problematic, with failures in many PPP contracts, including breakdowns and early termination of contracts. In fact, most PPP contracts are renegotiated. In a study for Latin America (sample of 1,000 contracts), Guasch discovered that $75 \%$ of the water concession contracts were renegotiated on average 1.6 years after their signature (Guasch 2004). Under this circumstance there is bilateral bargaining to restore a mutually acceptable situation for the parties, which undermines the legitimacy of the 
original contract award. Since there is no competitive environment at this stage, the operator will always have more information on the implications of alternative contractual arrangements, putting the private partners in a position to imposing their will (Bajari et al. 2005).

Most of the literature has focused on developing countries, where often the lack of transparency and expertise within newly democratic governments, lack of procedures to prevent corruption, and a national focus on industrialization might contribute to unsuccessful contractual arrangements. Nevertheless, experience around the world suggests that the failures of contract regulation are not a matter of stage of development: see, for example, the cases of Atlanta in the US water sector, the airport of Montreal in Canada, or the London underground in England.

This study draws lessons from a detailed analysis of two PPP case-studies in Portugal, one contractual (concession contract) and other institutionalised (mixed company) in the local sector. The institutionalised PPPs have been little discussed in the literature but are very important in some countries (e.g. the Société d'economie mixte in France, the Stadtwerke in Germany or the Empresa Mixte in Spain). This analysis represents a firststep towards better understanding the full implications of widely-utilized institutional arrangements. We conclude that in these cases the contract failures are even more serious than is generally recognised.

Portugal has a population of about 10.7 million inhabitants and is organized into districts, municipalities (the basis of the country's administrative structure), and parishes. Currently, Portugal has 18 districts, 308 municipalities and 4,257 parishes. In the European context, Portugal is highly centralized and local authorities' expenditures represent a smaller percentage when compared with Nordic countries which spend about five times more. The responsibilities of municipalities are minor (mainly in health, education and social protection areas) in Portugal. However, they are parallel to the other countries in Europe concerning other infrastructures. For example, responsibilities in the water sector are similar in all Europe (except UK, Netherlands and a few other cases), with water services located within the sphere of municipalities and the water policy in the regional or central governments. The Portuguese legislation is deeply influenced by EU legislation, particularly in public procurement. The scarce financial resources of municipalities have two important consequences. On the one hand, they limit investment in human resources and administrative structures. In addition, lack of financial resources leads to difficulty in contracting good consultancy services (experts). On the other hand, they are the major reason for the foundation and popularity of PPPs in the local administration in different sectors, since municipalities are always under financial pressure. However, PPPs have been utilised more as a financial tool than as a form of public procurement, which harms performance.

The remainder of this paper discusses PPPs in infrastructure, emphasising their strengths and limitations, contract design issues and the common reasons why some contracts fail. Next, it analyses different models of PPP and private sector participation in the water sector, particularly, in Portugal. Then, two actual PPP contracts are examined regarding two institutional arrangements. Key lessons for the design and monitoring of PPP contracts are drawn in the final section. 


\section{PPPs IN INFRASTRUCTURE SERVICES}

\section{Strength and limitations}

Implementation of PPP contracts in infrastructure public services has generated benefits in terms of efficiency, service quality, and network expansion (Murphy 2008; Vining and Boardman 2008 and Marques and Berg 2009). Compared with the full privatisation option, PPPs do not require very detailed information about costs, demand and other features of the projects, neither is a "traditional" regulatory agency or a contractual management agency required (Viscusi et al. 1995). In addition, PPPs do not promote overinvestment. During the contract length, the private partner is interested in maintaining a good reputation which constrains possible hold-up behaviour by the operator. The hypothesis of early termination of contract is possible and anticipated in contracts. Compared with public provision (even without considering funding needs), the advantages of PPPs are potentially greater. Beyond those anticipated in the contract, the PPP-holder captures additional gains associated with efficiency improvements and new service introductions (Crew and Zupan 1990). These profits will be passed on to the customers when the PPP concludes. Expected rents are captured by customers (government) in the competition for the market, where the abnormal profits were eliminated by competition. Even without considering better efficiency in the private sector (emphasised in some streams of literature), in fact the PPP-holder is more accountable to customers and to the government since its duties are defined in the contract, including penalties (and rewards). As a rule, the operator in a PPP provides a higher quality of service, and will more likely meet the predicted budget and the deadlines than a purely public organization. Furthermore, the (potential) better allocation of risks leads to the development of risk mitigation strategies, cost savings, and service quality improvements.

Supporters of both full divesture and public ownership provide a very different characterisation of PPP contracts from those noted above (see Williamson 1976). Critics point out the high information required, the need for a supervising entity responsible for contract management, the issue of overinvestment (either by minimum investments imposed or if the plan of investments was an award criterion), and the weak incentives for efficiency and innovation due to the possibility of renegotiation and ex-post opportunism. The PPP bidding stage is also criticised for being excessively complex and very slow and for imposing high costs on those preparing bids. Gaining access to the market is seen as an expensive game for participating bidders (often involving the "winner's curse"). Frequently, the best bid (when evaluated in a comprehensive fashion) is not accepted. Strategies of low-balling, where the winner expects to seek a contract renegotiation at a later stage, are common. Furthermore, the number of bidders is usually small raising the potential for collusive behaviour.

Another weakness associated with PPP contracts involves contract monitoring. Contracts are incomplete by nature. For example, supervising quality of service requires expertise and careful auditing procedures for company-provided data. Moreover, PPP providers will probably tend to underinvest and provide a lower quality of service. Unpredicted events, the application of sanctions and the need for mediating conflicts 
turn the monitoring of the contract into a fundamental task that should be performed by an expert and independent body.

This critique of PPP contracts argues that they lead to higher costs, due to the search for profits by private companies, the higher cost of private capital, and the increase in procurement costs. In addition, service quality could be low due to underinvestment and to the inability of the contract to specifically address all quality issues. Some argue that there is also a loss of public sovereignty (flexibility, transparency and accountability) with PPPs in practice (Phang 2007) and others point out that they can be controversial (Reeves 2008). As we will see next, most of the problems are related to contract design and can be addressed in a well-prepared contract.

\section{Contract Design Issues}

PPPs contracts can be classified into short-run and long-run (or incomplete) contracts (Lane 2001). The former have a length between one and five years, possibly up to 10 years and the latter have a length greater than 12 years (Klein 1998). Designing PPP contracts to be signed between the Government and the private operator is challenging and requires legal and technical expertise. The main issue is balancing the initial preparation costs (affecting the contract incompleteness) against the transaction costs generated by probable renegotiation. As ex-post opportunism and renegotiation represent major failures of a PPP contract, the public body should try to avoid this contingency. In order to do so, the following procedures must be accomplished:

1. Allocating risks to appropriate parties;

2. Guaranteeing the economic and financial equilibrium only for the contingent risks borne by the public partner;

3. Assigning payments based on outputs and performance;

4. Assuring that the winning bid is fulfilled when the contract is signed;

5. Constraining the possibility of bargaining after public bidding and contract signature, and

6. Clarifying the terms of early contract termination.

Generally, the choice between short-run and long-run contracts depends on the up-front investments or rents required. In the past, PPPs were often associated with long-run contracts since financing was the major issue. Currently, financing continues to be relevant but the risk associated with this type of contract has become more important, especially in developing countries.

\section{The Failures of Contracts}

There are several reasons for the failure of PPP contracts. They can be sorted into three groups, related to problems with conducting the bidding process, risk sharing, and monitoring (Marques and Berg 2009). These major sources of failure are briefly analysed below.

\section{a) Conducting the Bidding Process}

To avoid political favouritism, the choice of the private partner should be made by public bidding. With enough competition, excess profits will be eliminated. Normally, 
there are several criteria to award a PPP, leading to the application of multi-criteria decision analysis to determine the winner. Unfortunately, rarely is the assessment methodology provided in the public tender documents, which limits transparency and unnecessarily reduces information available to bidders about what the PPP-granting authority views as important. Most of the time, bids suffer from a number of problems, such as (1) assumptions underlying the bids are not comparable, (2) superficial elements are evaluated rather than the essential ones, (3) the principles initially proposed (in the bidding documents) suffer changes at the evaluation stage (or in second stage when it exists) or when the contract is signed; and (4) criteria like experience and financial health are considered as evaluation criteria instead of standards for bidder qualification.

\section{b) Managing and Sharing Risk}

The main theoretical benefit from PPPs is that the risks would be assigned to the contractual party that is best able to mitigate the risk or to bear it. The optimal allocation of risks minimises economic costs. In the EU (Eurostat), the rule is not to consider the PPP's charges in the public accounts if the private sector has to support at least two of the three risks (construction risk, demand risk, and availability risk). Moreover, most contracts have clauses protecting the private sector from bearing such risks while ensuring economic and financial equilibrium.

\section{c) Monitoring Contracts}

The role of monitoring the contract is similar to the role performed by an external regulator, though the former activity might involve a little less discretion. The major problems of monitoring are related to supervising service quality, resolving contractual disputes and customers complaints, applying sanctions and performance rewards, participating in potential renegotiation, addressing early termination of contracts, overseeing asset transfer, and specifying terms for the renewal of PPP contracts. The bidding documents should identify the resources required to carry out the PPP monitoring and be specific on how the monitoring will be performed, including (1) all reporting procedures, (2) the amount and circumstances under which sanctions can be applied, (3) procedures in the event of renegotiation, and (4) quality of service supervision and, particularly, the handling of complaints. The public discussion of PPP contract performance can be an effective tool (a name and shame policy) so that performance results should be known publicly on a regular basis. Note, however, that usually there is general legislation concerning customer complaints and contracts normally impose sanctions when they are not adequately dealt with. Contract monitoring is often omitted in the bidding documents, despite its centrality to PPP contract success.

\section{PPP IN WATER SECTOR}

\section{Different models}

As mentioned above, models of privatisation (without full divesture) can be classified into two major groups: contractual PPPs and institutionalised PPPs. In the first one, the 
partnership between public and private sectors is based solely on contractual links, whereas in a PPP of an institutional nature there is cooperation between the public and the private sectors within a distinct entity. Both arrangements involve delegated responsibility of production (operation), finance (although there are exceptions such as the affermage contracts) and the collection of tariffs before the end-users (with some exceptions like shadow tolls in transportation). In the first type of PPP, rights and obligations are regulated by an administrative contract, while in the second, they are guaranteed by the company's statutes and by the shareholder agreement. Contractual PPPs include concession, affermage and management contracts. The focus here will be on concession contracts since funding is frequently required and they are the ones most often applied. Of course, this model can have complications as to whether the project is bankable or not. Investor perceptions of associated commercial and operating risks affect the cost of capital. Nevertheless, concessions have benefits to the extent that equity can be leveraged and that private participation improves incentives for high performance. Such arrangements are primarily adopted when large investments are necessary or the governments are maximising up-front payments (rent-seeking). They are used recurrently in the water sector, as well as in other sectors, like transportation.

In the second model, the institutionalised PPP, the public sector and a private company usually create a third company to deliver an infrastructure service (although an existing public company may also sell part of its shares to the private sector). Generally, the public sector retains corporate control, while management of technical operations is normally carried out by the private company. At first glance, the model has sound principles, since sharing management responsibility can avoid some conflicts (Marra 2007). As the public sector is now more accountable, there is less imperfect information and disputes can be resolved internally.

Participants from the public sector exercise their authority (and political power) over infrastructure services by being able to appoint the board of directors, approve major decisions and participate in daily management. However, companies jointly owned by private shareholders and government can lead to the worst of both worlds, achieving neither high profitability nor worthwhile social goals (Boardman and Vining 2008). In institutionalised PPPs, only the statutes of the firm and a shareholder agreement document regulate the relationships between the partners.

\section{The Portuguese Experience}

In Portugal, the responsibility for the water activities belongs to the municipalities. There are 300 retail water utilities (for 308 municipalities and 10.7 million inhabitants) and about $70 \%$ of the water is provided by 18 public wholesale companies. Municipalities can opt for a number of arrangements, including the establishment of private companies by means of concession contracts, municipal companies which can include a (minority) private shareholder, semi-autonomous organizations, or direct supply by the municipality. Private participation was not introduced in the sector until 1993. The enactment of legislation in that year allowed local municipal authorities to delegate water service functions to private sector companies through a public tender by concession contracts (purely contractual PPP). With the opening of the market to private participation, it became necessary to monitor and supervise this activity so that the 
national government created a regulator (Institute for Regulation of Water and Waste IRAR) although without substantial economic regulatory authority. In 1998, new legislation allowed the creation of municipal companies, making it possible to found mixed companies (institutionalised PPP). In order to safeguard the principle of local autonomy, IRAR does not have authority over these companies or over the local administrative bodies in charge of the system's direct management.

Until December 2008, 38 public tenders for PPP were launched in the water sector, corresponding to more than 2.7 million inhabitants. As of that date, 29 contracts had been signed, with five cancelled and the rest still in negotiation. Of the 29, 24 correspond to a purely contractual PPP and five to institutionalised PPPs. The average length between the tender call notice and the contract signature was about 21 months. The average number of bidders was four: more than 30 different private companies participated in these public bidding procedures, including the well-known transnational companies. As a result, now there are five major private players in the Portuguese water sector; three are international operators. The water market in Portugal, despite being small, has been very appealing and has shown reasonable competition between tenderers. Furthermore, in line with earlier observations about the fragility of contracts, $50 \%$ of the PPPs have already been renegotiated. In the next subsections two empirical examples will be provided (anonymous municipalities) to analyse in more detail the causes for renegotiations and other failures. The authors had access the all documents concerning the foundation of these PPP (public tender documents, bidders, awarding and assessment reports, contract, shareholder agreement and others) because according to Portuguese law, they are classified as administrative documents requiring public access. Note that the problems identified and presented here do not necessarily mean negative outcomes. Usually these companies have higher performance when compared with the public ones in Portugal (Marques 2008).

\section{CASE-STUDIES}

\section{Purely contractual PPP: Municipality A}

The public tender documents and the signed contracts are quite similar in Portugal. The municipalities generally do not have competencies to perform these tasks; consequently, due to scarce resources, they hire local or low cost consultants with little experience in PPPs. In addition, municipalities, and particularly the mayors, tend to favour consultants they can trust politically. Frequently, the players themselves lobby the mayors and provide them with "draft" public tender documents. Consider a recent bidding in Municipality A which is similar to (or better than) typical biddings. Municipality A launched a contractual PPP, a concession with the length of 30 years for water and wastewater services. It embraced about 12,000 customers. The concession comprised only the retail segment since the municipality imported water from a public wholesale company and outsourced wastewater treatment. The municipality had a set of urgent investments amounting to 10 million Euros. It also asked for an annual payment (rent) which corresponded to a residual value (about 1 million Euros during the 30 yearperiod). There were seven bidders: the public tender stage (including the design of contract) took two years to complete. 


\section{a) Conducting the Bidding Process}

One of the major problems of this particular PPP was the absence of an economic and financial study of its viability. It is understandable that the municipality had not performed a public sector comparator study, but at least the public documents should have provided adequate elements about the operation and maintenance of the services and infrastructure records. This lack of data complicates the bid preparation process and increases the cost for bidders.

Table 1 presents the criteria for bid assessment and their weights. The average tariff criterion was computed using a formula specified in the bidding documents attributing $100 \%$ for the minimum tariff proposed: all the remaining points were computed in percentage terms according to this framework. The average tariff corresponds to the net present value of the sum of projected revenues, divided by the volume of water billed and by 30 (years). The remaining criteria were detailed during the public tender stage.

The methodology suffered from three very serious problems: lack of standardised assumptions, inappropriate (sub)criteria, and lack of consideration of the probability of renegotiation. First, the key-variables in the project were not standardised; thus, the bids were based on very dissimilar assumptions regarding population and customer growth, future consumption patterns, leakage targets, and macroeconomic variables. The differences in some of these factors reached almost 50\%: thus, the resulting bids were not comparable. This inconsistency clearly led to the winner's curse: the concessiongranting authority is likely to accept the most optimistic, rather than the best, proposal.

The second problem relates to non-economic (sub)criteria, which were inappropriate for a PPP. Part of these subcriteria constituted risk to be borne by the private firm. In addition, most of the other subcriteria (e.g. quality of service) should have been imposed and not subject to competition. They led to excessive discretion and complicated the evaluation process. The neutral criteria should also be avoided. Finally, the subcriteria should be assessed with an output based approach rather than with one that emphasises inputs.

At first glance we might think that the weights given to these subcriteria are small, so these elements are unlikely to affect the choice of the winner. However, these subcriteria are often evaluated in a comparative basis where there are usually 5 classifications, such as very good, good, reasonable, weak and very weak. The difference between very good and very weak counts $100 \%$ of its weight. In the average tariff, normally the one classified in first place gets $100 \%$ but the last one can have nearly $90 \%$; for this reason, the weight of $70 \%$ is not as relevant as it seems a priori. The subcriteria (flawed as they are) did affect in the final evaluation.

Finally, the criteria evaluated did not consider common problems of PPPs, like the probability of renegotiation. The robustness of the business case to potential adverse situations was not evaluated and the associated adjustments required for restoring the financial equilibrium were not considered (e.g. internal rate of return of shareholders). The documentation required in the subcriteria related to financial and contractual strength mainly focused on the equity put into the project by the private firm and on the 
letters from banks regarding project financing. These elements are indeed important, but the former is nearly always neutral because rather than a firm commitment, the bidder only makes known its financing intention.

\section{b) Managing and sharing the risk}

The second major failure of this regulatory contract is that the risk is not shared appropriately with the private sector. If we examine the clause regarding the restoration of economic and financial equilibrium in the public tender, translated in the signed contract (see Table 2), we observe that the most important risks are transferred to the municipality, and part of them are later transferred to the customers directly. Thus, as presented in Table 2 (and with some exceptions), the major risks are not borne by the private sector, penalising the public interest.

If we consider the consumption risk, the scheme displayed in Table 2 is highly perverse: encouraging excessive optimism and exacerbating the winner's curse. The PPP granting authority is doubly penalised: the best bidder may not be chosen if it predicts an optimistic volume and there is a high probability of needing to revise the contract to achieve its financial and economic equilibrium. Most of the other risks, except those related to unilateral changes by the municipality, should be borne by the private sector. For example, with this contractual clause, the private firm does not have incentives to predict other investments beyond those compulsory in the public tender documents. The consequences are quite visible since their inclusion in the bid diminishes the likelihood of the concession being awarded. The best strategy for the bidder is to negotiate directly with the municipality without competition after winning the bid. Of course, legal and the regulatory risks can be allocated to the public sector, or preferably passed onto customers. For such contingencies, it may not be necessary to deal with a negotiation. The contract signed between the private company and Municipality A also allocates rights of way or eminent domain (expropriation) and force majeure risks to the municipality.

\section{c) Monitoring Contracts}

This contract has problems with the application of sanctions. In addition to the reduced values (the most serious correspond to about $1 \%$ of an annual turnover), the scheme presumes that the public sector will actually apply a sanction to the private firm which has available a set of appeal mechanisms that may stop the process. An example of this difficulty is found in Portugal, where no sanction has ever been applied fifteen years after the first concession contract signature.

The major explanation for the absence of sanctions is that the burden of proof resides with the public sector rather than with the private operator. It is reasonable for the private firm to have various ways to defend itself, but the application of sanctions should be automatic, particularly those related to quality of service (e.g. customers receive a payment if a complaint is not handled adequately). Note that the issue of service quality monitoring is particularly troublesome under regulation by contract. In Portugal, it is mitigated by the existence of an external regulator (IRAR). 
A second issue is the possibility of earlier termination of the contract at the initiative of the public partner. The conditions of early termination tend to be draconian, including significant compensation for the operator or reducing the value of this mechanism for the public partner. Consequently, in Portugal there has never been a PPP contract termination in any sector! The particular contract for "Operator A" includes return of not only the non-depreciated investments made and the debt payment, but also the net present value of the "annual lost returns on equity" for all years between the moment of termination and the end of the contract and $20 \%$ of technical assistance contract for that period. Since the technical assistance contract represents about $4 \%$ of the turnover, it corresponds to $0.8 \%$ of the turnover in each remaining year. This weakens the performance of PPP projects and is detrimental to the public interest.

Finally, the supervision of the investment plan and the quality of the assets deserve attention. There are clauses in the contract which regulate the transference and the state of the assets (particularly the renewal), imposing a requirement that investments should be maintained to have a life expectancy comparable to two thirds of their life cycle. This implies significant investments that should be supervised by the public authority. Nevertheless, this particular contract did not determine how this would be done; nor did it specify the consequences if the private sector was unable to fulfil its investment obligations. In the authors' opinion, outcome targets should be imposed rather than investment obligations. However, if minimum investments were predictable, at least in the renewal period, there would be the possibility of mitigating conflicts, discretion and misunderstandings in future bidding processes.

\section{An Institutionalised PPP: Municipality B}

Only seven public biddings of institutionalised PPPs were launched between 1998 and 2008. Although the public tender documents were similar, some of them allowed for a second stage of explicit negotiation. When both partners fully understand the project the two bids which pass into the second stage improve significantly their proposals: they have more time to conduct more studies and therefore gain better insight into the project. The fierce competitive environment often generated is highly positive. Usually, in the second stage the criteria negotiated consist of the value of shares sold by the municipality (usually representing $49 \%$ of shares) if the bids are similar. However, the bidder(s) might be asked to improve a particular criteria to a higher desired level or, at least, to the level of the other bidder.

Municipality B called for an institutionalised PPP (mixed company) which included water, wastewater and stormwater services. The private firm would have $49 \%$ of the shares and the municipality would retain the remaining 51\%. The term of the PPP was indefinite (on the whole it is established for a specific period, for example 30 or 40 years); the municipality would only negotiate with the firm classified in second place if the negotiation with the winner was not successful. Having a potential rival "in the wings" puts some pressure on the first stage winning bidder to bargain in a reasonable manner. The PPP encompassed more than 30,000 customers and included wholesale and retail segments. The municipality had a set of critical investments to be carried out representing about 60 million Euros. The municipality also asked for an up-front single 
payment of 18 million Euros (for $49 \%$ of shares). Six bidders participated in the public tender.

\section{a) Conducting the Bidding Process}

To create the mixed company (and to call for bidding) it is necessary to present an economic and financial viability study to allow the municipality to better understand its situation; similarly, the information provides bidders with substantial data. Yet, the process can have a perverse effect, as occurred in this case. For example, the up-front payment to the municipality did not include a commensurate increase in the average price. The evaluation criteria, despite having a better structure than in typical concession contracts, still had problems (see Table 3).

Table 3 highlights that some criteria are inappropriate (they do not differentiate among bidders or merely complicate the evaluation process) and, consequently, the selection of the winning bid that is not necessarily the "best". Most of the subcriteria for B (appropriateness of the proposed investment plan) and $\mathrm{C}$ (quality of bid) are either arbitrary or non-informative. Additional items only increase the complexity of evaluation, foster undue discretion, and raise the cost of bid preparation. However, the most serious problems occur with the more important criteria: A (average tariff), D (economic and financial viability) and $\mathrm{E}$ (governance and shareholder benefits).

The average tariff is computed as usual: the ratio of the net present value of revenues and the cumulative volume of water billed. However, only the revenues of water and wastewater activities were included; stormwater revenues, which by law are not directly billed to the customers, were not incorporated. Nevertheless, the municipality (with taxpayer funds) can transfer to the mixed company the amount corresponding to stormwater cost. For this particular bid process, this portion was not evaluated; yet, this component differs dramatically among bidders (a fivefold difference between the "best" and the "worst" bid). Since some bidders recognised this inconsistency, they took advantage of the scoring system by increasing substantially payments for this particular service.

The viability study of the company comprises part of the bidding document; therefore all bids should be based on its pre-specified assumptions, including population forecasts and expected trends in consumption per capita. Nevertheless, there was room for creative accounting in the evolution of these variables between the first and the last year. Furthermore, the bidding document (base case) study and associated assumptions justifying the 18 million Euro payment (and only a small price change) was very optimistic, leading to unrealistic volumes of water billed. Consequently, the business case would need to be altered within a few years of the partnership. Hence, it would be crucial to give greater weight to the conditions demanded by the private firms to participate in this game, for example the internal rate of return of shareholders and other financial indicators that make the mixed company vulnerable. By de-emphasising relevant factors and giving weight to less important (or less discriminating elements), the system seems designed to fail in the search for the "best" bid. 
One critically important aspect of the evaluation is the cost structure, which is only worth $1 \%$ of this particular evaluation scheme. In addition to the traditional costs, which should be analysed, particular features determine whether a bid is good (realistic) or bad (likely to lead to renegotiation). For example, the charges for the stormwater activity and all the fees related to management, technical assistance and other charges (which can amount to substantial sums) are evaluated here with a weight of $1 \%$. Other concerns include the structure of financing and the end-point.

Last (but not the least) the weight given to the proposal of statutes and shareholders' agreement is unreasonably low (only 5\%). In this kind of PPP, the regulatory contract corresponds to the shareholders' agreement (and also to the statutes) where the relationship between the partners is established, and the operating rules for the company are defined (including the allowed rate of return and the financial indicators that affect tariff reviews). In addition, the shareholders' agreement specifies the nature of the call option, which corresponds to an early termination of the contract required by the municipality. As time passes, the winner's initial bid loses importance as investments, tariffs and other conditions are changed. However, the statutes and the shareholders' agreement remain in force. These documents regulate the PPP: they should not be of minor importance in the evaluation.

\section{b) Managing and sharing the risk}

The problem of risk sharing is more serious in the case of institutionalised PPPs. Indeed, mixed companies do not bear risks: they are transferred to customers. The bidding documents identify the situations that constitute the causes for restoring the financial and economic equilibrium of the mixed company considered here, as shown in Table 4.

These clauses relate to almost all the risky situations, though with some imprecision. However, the shareholder agreement document clarifies these circumstances by establishing the conditions where a change in the proposed main financial indicators is recovered in the next tariff review (annual). Thus, the rate of return and other indicators are always guaranteed. The risks are not supported directly by the municipality and the benefits of this arrangement belong to the municipality as well (51\%), although management and other fees paid directly by the mixed company accrue to the private firm and its managers. However, customers bear the risk and costs can drift upwards, leading the authors to conclude that the public interest is harmed by poor contract design in this instance.

In line with the literature, these PPP contracts show a high failure probability (Boardman and Vining 1989; Jamison et al. 2005). Since the municipality is inside the mixed company, political and ethical difficulties may generate controversies due to the duty of protecting the public interest and simultaneously remaining loyal to its partner, (especially because of its co-responsibility for key decisions). Furthermore, a dispute leading to a deadlock may compel the municipality to purchase shares under the call option, which is unacceptably costly in economic terms. So, there is a tendency for the public partner to accept all the requirements of the private partner and transfers to the customers the risks that should be borne by the private partner or assumes them 
straightforwardly. This category of PPP, in general, yields an inferior performance when compared with the other kinds of PPPs or even with direct public sector provision. This is in accordance with a recent study that found negative productivity growth for Portuguese municipal companies, including mixed ones; this performance is worse than under either public or private service provision (Cruz and Marques 2009).

\section{c) Monitoring the contracts}

The public partner responsible for monitoring is part of the process and has more responsibilities than the private partner. Hence, it is unlikely that it will apply sanctions or take measures against itself. As it is co-responsible for the activity of the mixed company, it tends to accept proposals to raise tariffs without much resistance. The answer to the complaints is also penalised (due to the partiality in dealing with them) as there is no municipality to complain about in the first instance. The existence of an external regulator provides oversight in some countries; however, in Portugal, such regulation is not possible yet because it interferes with local autonomy. Service quality is not so troublesome since the private firm is interested in increasing capital expenses and in over-capitalisation if the return is greater than the cost of capital (AverchJohnson Effect). Moreover, there is often a contractor who promotes investments because of its higher profit margins. Experience indicates that contractors have abnormally high margins (50 to $100 \%$ more than traditional public works procurement). One alternative would be to have two contracts, one for investments in infrastructures and other for operating the service (Hart 2003). Another possibility would be making the public tender compulsory for all new works that may occur ex-post (Chong et al. 2006).

The problem of contract renegotiation and tariff adjustment is also related to the call option. In mixed companies, the specified compensation arrangements greatly penalise the public partner and the threat of ending the PPP does not exist. Normally, besides reimbursing the private partner for non-depreciated investments and existing debt, the compensation includes the discounted sum of shareholder net cash-flows which are yet to be received (say, for 30 years), plus the discounted residual value plus a percentage of the turnover of previous or subsequent years. To complicate the situation, every time parties disagree, there could be a deadlock. The shareholder agreement document states that if the dispute is not resolved within a short deadline (30 days), the public partner must exercise the call option. Thus, the contract is structured so that the private firm is likely to attain its objectives.

\section{CONCLUDING REMARKS}

This paper discussed the regulatory contracts for PPPs in infrastructure industries. Using two cases from the Portuguese water sector, two approaches of PPP and regulation by contract were compared: the purely contractual PPP (concession) and the institutionalised PPP (mixed firm).

The theoretical model of institutionalised PPPs is not reflected in the contracts as they are actually being drawn up. The authors acknowledge the soundness of the theoretical 
principles, but the problems of designing and implementing regulatory contracts are much more serious than generally recognised in the literature. What can be done? First, it is important to recognise the role of an external regulator from the very start of the tender design process. Second, the design of public tender documents should include automatic mechanisms related to contract monitoring (e.g. penalties). Third, at all stages, procedures should ensure transparency and accountability. For example, tariff proposals should be subject to a standard administrative procedure, including customer and other stakeholder participation; major decisions should be publicly approved in the Municipal Parliament, not in closed meetings between self-interested parties. Finally, in addition to being subject to corporate law, the mixed company should fulfil the major principles related to public law, such as publicising public access to reports.

The two different PPPs analysed above (contractual and institutionalised PPPs) suggest some key lessons for the future. One can identify eight key principles that are fundamental for successful PPPs and effective regulation by contract. Notice that in municipalities (and other local bodies) these PPP tenders are, a priori, only launched once and therefore it is difficult to have a learning process here. Thus, the fulfilment of these principles becomes even more important.

1. Design Tender Documents with Great Care: The design of public tender documents is the cornerstone of a successful PPP. The signed regulatory contract is constrained by the bid itself, which (in turn) depends on the tender documents. Inappropriate simplifications and poor design at this stage jeopardise the success of the PPP over its economic life. Sometimes, politicians seek discretion in the bid evaluation process, which runs counter to designing and awarding a contract whose aim is to protect the public interest. Template documents should be defined, recognising that 'one size fits all' is not acceptable. The draft of a proposed contract design should be provided as an annex in the public tender documents.

2. Establish Accountability to an External Regulator: Having an external independent entity (regulator) monitoring the PPP benefits citizens. Its involvement should begin with the design of tender documents, since local authorities granting the PPPs are unlikely to have the experience, resources, and expertise required for such work. Even when the law gives final authority to local municipalities, the external regulator can provide a reality-check on the terms and conditions of the contract and can support the municipality in evaluating the performance of the PPP.

3. Prepare Baseline Studies: There is strong evidence of the need for more comprehensive studies prior to launching a PPP. It is likely that one more Euro spent at this stage represents savings of several Euros in the future. The optimal situation should involve developing a public sector comparator (a baseline) and providing bidders with a template for a business plan that would pass a benefitcost test. The analysis of municipalities' associations, which allow for savings via economies of scale and scope, should also be carried out. At a minimum, the documents should provide complete information about trends in infrastructure 
system operations and the objectives of the PPP. Samples of the kinds of information required during the monitoring process are important as well.

4. Priorise Selection Criteria: The cases underscore the importance of choosing the right criteria for selecting a private partner. A PPP contract is different from traditional procurement (public works or outsourcing contracts). Since the probability of renegotiation and alteration of the initial regulatory premise is substantial, the criteria should include an analysis of how such situations are to be mitigated and when disputes occur, how the public interest is to be defended. In addition, some of the technical and quality criteria should be imposed, and not be subject to competition.

5. Facilitate Competitive Bidding: Competition should be facilitated since competition for the market is one of the most important benefits of this model. Preferential treatment of particular competitors is totally inappropriate. More bidders for the PPP imply more value for money. Only the documentation strictly necessary should be required, reducing the high costs for participating in the bidding process.

6. Allocate Risks in an Explicit Manner: An appropriate allocation of risks is fundamental for the success of the PPP, not only to minimise the likelihood of renegotiation but also to save money (mitigating risks, thus reducing the economic cost of bearing risk). Thus, the contract should provide the right incentives to the private partner. A risk matrix should be provided as an annex in the public tender documents, allocating each risk to the respective contractual clause.

7. Simplify Monitoring and Sanction Procedures: The process of monitoring must be simplified (to reduce red tape and to identify clear contract violations). Therefore, the application of sanctions related to customer service quality should be implemented automatically, along with performance rewards at the organizational level.

8. Ensure Transparency: All the activity of a PPP-holder should be endowed with transparency. For example, procedural transparency should be present during the process of setting prices, evaluating metrics, and approving business plans: all the stakeholders deserve to be informed of actions affecting their welfare. Publicising PPP firm activity promotes accountability and facilitates yardstick comparisons (which are essential for public input).

\section{REFERENCES}

Bajari, P., S. Houghton and S. Tadelis. 2006. 'Bidding for Incomplete Contracts: an Empirical Analysis', Working Paper, no. 12051, NBER.

Boardman, A. and A. Vining. 1989. 'Ownership and performance in competitive environments: a comparison of the performance of private, mixed, and State-owned enterprises', Journal of Law and Economics, 32, 1, 1-33. 
Chadwick, E. 1859. 'Results of different principles of legislation and administration in Europe: of competition for the field, as compared with the competition within the field of service', Journal of the Royal Statistical Society, 22A, 381-420.

Chong, E., F. Huertand S. Saussier. 2006. 'Auctions, ex post competition and prices: The efficiency of public-private partnerships', Annals of Public and Cooperative Economics, 77, 4, 521-554.

Chui, Y. 2003. 'Estimating the cost efficiency of mixed enterprises in Taiwan'. International Journal of Management, 20, 81-87.

Crew, M. and M. Zupan. 1990. 'Franchise bidding for public utilities revisited', in M. Crew (ed.), Competition and the Regulation of Utilities. Boston: Kluwer Academic Publishers, pp. 173-188.

Cruz, N. and R. Marques. 2009. 'Viability of the Portuguese municipal companies in provision of infrastructure services', Forthcoming in Local Government Studies.

Demsetz, H. 1968. 'Why regulate utilities?', Journal of Law and Economics, 11, 1, 5565.

Gassner, K., A Popov and N. Pushak. 2009. Does Private Sector Participation Improve Performance in Electricity and Water Distribution? Washington D. C.: PublicPrivate Infrastructure Advisory Facility (PPIAF). World Bank.

Guasch, J. 2004. Granting and renegotiating infrastructure concessions: doing it right. Washington, D.C.: World Bank.

Hart, O. 2003. 'Incomplete contract and public ownership: remarks, and an application to public-private partnerships', The Economic Journal, 113, 69-76.

Jamison, M., L. Holt and S. Berg. 2005. 'Measuring and mitigating regulatory risk in private infrastructure investment', The Electricity Journal, 18, 6, 36-45.

Klein, M. 1998. 'Bidding for concessions', World Bank Policy Research Working Paper no. 1957, Washington D. C.: World Bank.

Lane, J. 2001. 'From-long term to short-term contracting', Public Administration, 79, 1, 29-47.

Marra, A. 2007. 'Internal regulation by mixed enterprises: the case of the Italian water sector', Annals of Public and Cooperative Economics, 78, 2, 245-275.

Marques, R. 2008. 'Comparing private and public performance of Portuguese water services', Water Policy, 10, 1, 25-42.

Marques, R. and S. Berg. 2009. 'Revisiting the strengths and limitations of regulatory contracts in infrastructure industries', PURC Working Paper.

Murphy, T. 2008. 'The case for public-private partnerships in infrastructure', Canadian Public Administration, 51, 1, 99-126.

Phang, S. 2007. 'Urban rail transit PPPs: Survey and risk assessment of recent strategies', Transport Policy, 14, 3, 214-231.

Reeves, E. 2008. 'The practice of contracting in public private partnerships: transaction costs and relational contracting in the Irish schools sector', Public Administration, 86, 4, 969-986.

Vining, A. and A. Boardman. 2008. 'Public-private partnerships. Eight rules for Governments', Public Works Management \& Policy, 13, 2, 149-161.

Viscusi, W., J. Vernon and J. Harrington. 1995. Economics of Regulation and Antitrust. $2^{\text {nd }}$ edn. Cambridge: The MIT Press.

Williamson, O. 1976. 'Franchising bidding for natural monopolies - in general and with respect to CATV', Bell Journal of Economics, 7, 1, 73-104. 
Table 1 - Criteria and Weights for a Purely Contractual PPP

\begin{tabular}{|c|c|c|c|}
\hline Criteria & Subcriteria & \multicolumn{2}{|c|}{ Weighting } \\
\hline \multicolumn{2}{|c|}{ A) Average tariff } & $\mathbf{7 0 \%}$ & \\
\hline \multicolumn{2}{|c|}{ B) Quality of service } & $10 \%$ & \\
\hline & B.1) Quality of studies & & $25 \%$ \\
\hline & B.2) Procedures of operation, maintenance and control & & $25 \%$ \\
\hline & B.3) Procedures of reading, billing and collection & & $15 \%$ \\
\hline & B.4) Procedures of supervision and control of works & & $20 \%$ \\
\hline & B.5) Procedures and schedule of quality certifications & & $15 \%$ \\
\hline \multicolumn{2}{|c|}{ C) Safety of the provision } & $10 \%$ & \\
\hline & C.1) Technical staff and their organization structure & & $35 \%$ \\
\hline & C.2) Capability to respond in emergencies & & $50 \%$ \\
\hline & $\begin{array}{l}\text { C.3) Access to technical resources and their } \\
\text { appropriateness to their investment plan }\end{array}$ & & $15 \%$ \\
\hline \multicolumn{2}{|c|}{ D) Strength of financial and contractual structure proposed } & $4 \%$ & \\
\hline & D.1) Proposal of tariff system & & $50 \%$ \\
\hline & D.2) Financing model & & $25 \%$ \\
\hline & $\begin{array}{l}\text { D.3) Appropriateness of the financial projections } \\
\text { considering the plan of proposed investments }\end{array}$ & & $25 \%$ \\
\hline \multicolumn{2}{|c|}{ E) Quality and appropriateness of the plan of proposed investments } & $4 \%$ & \\
\hline & E.1) Ability to meet the service coverage targets & & $60 \%$ \\
\hline & E.2) Scheduling of the tasks & & $40 \%$ \\
\hline \multicolumn{2}{|c|}{ F) Payment to the municipality and its temporal distribution } & $2 \%$ & \\
\hline
\end{tabular}

Table 2 - Risks leading to PPP financial and economic equilibrium restoration

\begin{tabular}{ll}
\hline \hline Changes requiring restoration of financial/economic equilibrium & Risk \\
\hline $\begin{array}{l}\text { Change greater than } 20 \% \text { (up or down) of the annual volume of } \\
\text { water distributed predicted by the bidder }\end{array}$ & Consumption \\
$\begin{array}{l}\text { Change greater than } 20 \% \text { (up or down) of the annual volume of } \\
\text { wastewater collected predicted by the bidder }\end{array}$ & Consumption \\
$\begin{array}{l}\text { Expansion or reduction of the system scope concerning the works } \\
\text { predicted by the concessionaire }\end{array}$ & Several \\
$\begin{array}{l}\text { Change of the amount of investments proposed by the business case } \\
\text { of concessionaire }\end{array}$ & Several \\
$\begin{array}{l}\text { Meaningful change of the rules or legislation which leads to the } \\
\text { alteration in equipments and procedures }\end{array}$ & Legal/regulation/operation \\
$\begin{array}{c}\text { If the concessionaire has to bear charges related to the factors that } \\
\text { could not be predicted at the date of contract signature as, for } \\
\text { example, new taxes, tariffs or taxes determined by new legislation }\end{array}$ & Legal/regulation \\
$\begin{array}{c}\text { Change greater than } 20 \% \text { of the annual average value of Euribor (6 } \\
\text { months) when compared with the previous year }\end{array}$ & Financing \\
$\begin{array}{c}\text { If the price of wholesale services (water and wastewater) suffer a } \\
\text { change different from the one proposed at the date of public } \\
\text { tender }\end{array}$ & Operation \\
\hline \hline
\end{tabular}


Table 3 - Criteria and weights for an institutionalised PPP

\begin{tabular}{|c|c|c|c|}
\hline Criteria & Subcriteria & \multicolumn{2}{|c|}{ Weighting } \\
\hline \multicolumn{2}{|l|}{ A) Average tariff } & $50 \%$ & \\
\hline \multicolumn{2}{|c|}{ B) Appropriateness of plan the investments proposed } & $20 \%$ & \\
\hline & B.1) Technical quality of designs & & $30 \%$ \\
\hline & B.1.1) General design of the infrastructure & & $60 \%$ \\
\hline & $\begin{array}{l}\text { B.1.2) Survey of current situation and description of } \\
\text { infrastructures assets }\end{array}$ & & $40 \%$ \\
\hline & B.2) Scheduling of work tasks & & $40 \%$ \\
\hline & B.2.1) Management, supervision and control of work & & $60 \%$ \\
\hline & B.2.2) Management of contingencies in work & & $40 \%$ \\
\hline & $\begin{array}{l}\text { B.3) Specifying the required service coverage targets } \\
\text { and linking these to compulsory investments }\end{array}$ & & $30 \%$ \\
\hline \multicolumn{2}{|l|}{ C) Quality of bid } & $10 \%$ & \\
\hline & C.1) Procedures for meter reading, billing and collection & & $20 \%$ \\
\hline & $\begin{array}{l}\text { C.2) Procedures for receiving, processing, and } \\
\text { addressing complaints }\end{array}$ & & $20 \%$ \\
\hline & C.3) Control of quality & & $20 \%$ \\
\hline & C.4) Training plan & & $20 \%$ \\
\hline & C.5) Information System & & $10 \%$ \\
\hline & C.6) Strategy to pick up new customers & & $10 \%$ \\
\hline \multicolumn{2}{|c|}{ D) Economic and financial viability study for a period of $\mathbf{3 0}$ years } & $10 \%$ & \\
\hline & D.1) IRR of the project & & $40 \%$ \\
\hline & D.2) Equity to total assets evolution & & $20 \%$ \\
\hline & D.3) Return on equity evolution & & $10 \%$ \\
\hline & D.4) Appropriateness of the structure of costs & & $10 \%$ \\
\hline & D.5) Financing structure & & $10 \%$ \\
\hline & $\begin{array}{l}\text { D.6) Appropriateness of the financial projections, } \\
\text { considering the proposed investment plan }\end{array}$ & & $10 \%$ \\
\hline \multicolumn{2}{|c|}{ E) Proposal of statutes and shareholders' agreement } & $5 \%$ & \\
\hline & $\begin{array}{l}\text { E.1) Company governance structure and conditions for } \\
\text { nominating members of governing bodies }\end{array}$ & & $50 \%$ \\
\hline & E.2) Conditions for the municipality call option & & $30 \%$ \\
\hline & E.3) Proposal of fair distribution between shareholders & & $20 \%$ \\
\hline \multicolumn{2}{|c|}{ F) Statements of commitments of guarantee of investments } & $5 \%$ & \\
\hline & F.1) Quality of bank which provides the letter of credit & & $50 \%$ \\
\hline & F.2) Quality of the letter of credit & & $50 \%$ \\
\hline
\end{tabular}




\section{Table 4 - Risks leading to PPP financial and economic equilibrium restoration}

\begin{tabular}{ll}
\hline \hline Changes requiring restoration of financial/economic equilibrium & Risk \\
\hline $\begin{array}{c}\text { Abnormal change of volumes not predicted in the economic and } \\
\text { financial viability study of the public tender }\end{array}$ & Consumption \\
$\begin{array}{c}\text { Significant expansion of capacity requirements not predicted in the } \\
\text { Plan of Investments }\end{array}$ & Several \\
$\begin{array}{c}\text { Meaningful change of the rules or legislation which leads to the } \\
\text { alteration of the conditions reflected in the initial bid }\end{array}$ & Legal/regulation \\
$\begin{array}{c}\text { If the mixed company has to bear charges related to the factors that } \\
\text { could not be predicted at the date of shareholder agreement } \\
\text { signature as, for example, new taxes, tariffs or taxes determined } \\
\text { by new legislation }\end{array}$ & Legal/regulation \\
$\begin{array}{c}\text { Change greater than } 30 \% \text { of the annual average value of Euribor }(6 \\
\text { months) relative to the date of signature of financing contract }\end{array}$ & Financing \\
$\begin{array}{c}\text { If there is any unilateral change initiated by the municipality, } \\
\text { implying changes in the business case of contract }\end{array}$ & Unilateral changes \\
\begin{tabular}{c} 
If some form of force majeure takes place \\
\hline \hline
\end{tabular} & Force majeure \\
\hline
\end{tabular}

